\title{
Resources and Strategies Used by Young Parents in Serbia
}

DOI: $10.5613 /$ rzs.50.3.2

UDC 316.362.1(497.11)

364.6

Original research article Received: 20 September 2019

\author{
Dragan STANOJEVIĆ \\ Department of Sociology, Faculty of Philosophy, University of Belgrade, Serbia \\ draganstanojevich@gmail.com
}

\section{Smiljka TOMANOVIĆ}

Department of Sociology, Faculty of Philosophy, University of Belgrade, Serbia smiljka.tomanovic@gmail.com

\section{Milana LJUBIČIĆ}

Department of Sociology, Faculty of Philosophy, University of Belgrade, Serbia milanaljubicic@yahoo.com

\section{ABSTRACT}

The paper deals with resources available to young parents and the strategies they deploy as a response to various domain-related demands (housing, finance, work, family). First, the structural and cultural features of the social context in Serbia are discussed as the framework for the study. Secondly, the paper analyses young parents' differences, by socioeconomic status (SES) and gender, regarding their resources, such as housing, finances, and employment, as well as their strategies. The analysis is based on a mixedmethods approach, which brings together the survey results of a sub-sample of 435 parents from a nationally representative survey of young adults aged 18 to 35 , and a qualitative analysis of semi-structured interviews with 24 young mothers and fathers. The analyses indicate significant SES and gender differences in young parents' resources and strategies, which are shaped by the structures and cultures of parenthood specific to the contemporary social context in Serbia.

Key words: $\quad$ young parents, resources, strategies, mixed methods, Serbia. 


\section{INTRODUCTION ${ }^{1}$}

Between the two focal processes of transition to adulthood, from education to work and family transitions (Walther, Stauber and Pohl, 2009), the latter is perceived as central and more significant among young people in Serbia (Tomanović and Ignjatović, 2006, 2010). The paper deals with resources available to young parents and the strategies they deploy as a response to different domain-related demands (housing, finance, work, family). It has two exploratory goals. The first is to explore how social context, with its structural and cultural features, influences resources and strategies available to young parents. By focusing on the integration of young parenthood within a particular socio-cultural context, the paper contributes to comparative research on the transition to parenthood (Nilsen, Brannen and Lewis, 2013a; du Bois-Reymond, 2008), among which studies conducted in the SEE region are particularly rare (e.g., Kovacheva, 2010). The second goal is to analyse the differences and inequalities in the socioeconomic status (SES) of young mothers and fathers in Serbia that affect the different strategies they deploy in providing the basic resources for parenting.

The paper is divided into five parts. The first part briefly introduces the conceptual framework and the second explains the mixed-methods approach the research is based on. The third part presents the main features of the social context that constitute the structural and cultural framework for young parenthood. The subsequent section of the paper presents the findings of the analysis of resources available to young parents and the strategies they deploy, with a focus on SES and gender differences, as well as inequalities among parents. The concluding part discusses the specificities of parenthood in Serbia from a comparative perspective, and how structural and cultural features of the social context, including SES and gender differences, shape the resources and strategies employed by young parents.

\section{CONCEPTUAL FRAMEWORK}

The analytical plan of the paper is based on the combination of two theoretical perspectives - transition to parenthood and fit and balance of different life domains. Research on the transition to adulthood and life course provides us with the theoretical and methodological framework to analyse the sociological aspects of the transition to parenthood. Despite numerous social, political, economic and family life changes, research shows that in most European cultures, parenthood is still the most important anticipated event in the life course of an individual, which marks the

Some analyses presented in this article were previously published as part of the study by Tomanović, Stanojević and Ljubičić (2016). 
transition to adulthood and becoming an adult in a full sense (du Bois-Reymond, 2008). Each phase of the transition to parenthood is shaped by cultural, structural and interpersonal factors (Nilsen et al., 2013a). Social class, level of education and income are factors that significantly shape young parenthood, but some other dimensions associated with cultural patterns, e.g., informal family support in Southern and Eastern Europe, modify the structural conditions of being a parent in different social contexts (Nilsen et al., 2013a: 3).

Research shows notable social class differences in family trajectories among young people across Europe (Nilsen et al., 2013b; du Bois-Reymond, 2008). Higher education, which is more accessible to middle-class youth is related to later family formation and fewer children compared to young people from lower classes. In middle-class couples, both partners are more likely to work, have stable jobs and earn a better income, make better use of institutional support, and rely less on informal childcare networks. Uncertainty of the labour market in male-breadwinner societies can cause the postponement of family formation for men, but for women from lower social strata, "family formation and taking the domestic role of housewife and/or mother is one type of strategy ... in order to reduce uncertainty" (Mills and Blossfeld, 2003: 210). In most European countries, "parents of lower-class backgrounds have more kin-based networks in comparison with high-status parents whose networks are clearly more status and profession-bound" (du Bois-Reymond, 2008: 129).

Work-family balance is usually seen as the compatibility of the roles in family and work domains which are negotiated with the partner and other family members, or a lack of conflict or interference of these roles (Grzywacz and Carlson, 2007; Frone, 2003). We find Voydanoff's (2005) analytical framework that identifies demands, resources and strategies as key elements for studying work-family fit and balance useful as a starting point for exploring work and family domains in young parenthood. Voydanoff defines demands as "structural or psychological claims associated with role requirements, expectations, and norms to which individuals must respond or adapt" and resources as "structural or psychological assets that may be used to facilitate performance, reduce demands, or generate additional resources" (Voydanoff, 2005: 823). We have modified her model by including several other variables related to additional dimensions (elaborated below), and by redefining the concept of strategies (Table 1). Although Voydanoff defines strategies as individual and family actions targeted at reducing the misfit between work and family demands and resources (Voydanoff, 2005: 832), she focuses on individual adjustments, decisions and actions. In contrast, we assume strategies to generate from group interaction ${ }^{2}$, as well as from the couple's negotiations. Therefore, we

This is supported by the conceptualisations of household strategies (Wallace, 2002; Bagić et al., 2017; Babović, 2009), emphasising the group (household) as a unit of analysis (not individuals). 
use the term "couple strategies" to refer to the couple's decisions and adjustments employed to meet the demands placed on the family as a whole and the specific (gender) roles within it.

Table 1: $\quad$ Transition to Parenthood - Demands, Resources and Strategies

\begin{tabular}{|c|c|c|c|}
\hline Housing & Finances & Work & Family \\
\hline \multicolumn{4}{|c|}{ Domain-related demands } \\
\hline $\begin{array}{l}\text { Independent } \\
\text { household }\end{array}$ & $\begin{array}{l}\text { Financial } \\
\text { independence }\end{array}$ & $\begin{array}{l}\text { Nonstandard work } \\
\text { schedules }\end{array}$ & $\begin{array}{l}\text { Care for children } \\
\text { Household chores }\end{array}$ \\
\hline \multirow{3}{*}{$\begin{array}{l}\text { Independent unit(s) } \\
\text { within the parental } \\
\text { household }\end{array}$} & $\begin{array}{l}\text { Women's financial } \\
\text { independence }\end{array}$ & $\begin{array}{l}\text { Overtime work } \\
\text { Job insecurity }\end{array}$ & Partner/spouse demands \\
\hline & $\begin{array}{l}\text { Sufficient funds for } \\
\text { basic needs }\end{array}$ & & \\
\hline & $\begin{array}{l}\text { Sufficient funds for } \\
\text { leisure activities }\end{array}$ & & \\
\hline
\end{tabular}

Domain-related resources

$\begin{array}{llll}\text { Inherited flat/house } & \text { Income from work } & \text { Flexible schedule } & \text { Partner support } \\ \begin{array}{l}\text { Large enough } \\ \text { parental household }\end{array} & \text { Social transfers } & \text { Parental leave } & \text { Kin support } \\ \begin{array}{l}\text { Sufficient funds to } \\ \text { buy apartment }\end{array} & \text { Income from rents } & \begin{array}{l}\text { Time off for family } \\ \text { Sensitive work- }\end{array} & \\ & \text { Parental support } & \text { family culture } & \end{array}$

Domain-related strategies

Reduce demands

\begin{tabular}{|c|c|c|c|}
\hline $\begin{array}{l}\text { Living within the } \\
\text { parental household } \\
\text { Living in the same } \\
\text { room with children }\end{array}$ & $\begin{array}{l}\text { Cutting expenses } \\
\text { Covering only basic } \\
\text { needs }\end{array}$ & $\begin{array}{l}\text { Leaving regular job } \\
\text { Working part-time } \\
\text { Working for less } \\
\text { income }\end{array}$ & $\begin{array}{l}\text { Parental role versus } \\
\text { career trade-off with } \\
\text { spouse } \\
\text { Less time with childre }\end{array}$ \\
\hline
\end{tabular}

Increase resources

Buy property by

themselves

Property bought by

parents

Extend living space
Additional jobs

More working hours/overtime work

Produce own food

Parental financial support

In-kind transfers
Kin support for child care

Kin support for household chores

Hire professional care/ household chores

Conceptualisation based on modified Work-family fit and balance model (Voydanoff, 2005: 826).

We have included establishing an (independent) household, and couples achieving financial/material autonomy as additional variables since we believe that the perspective on the transition to parenthood that takes into account work-family 
relations would benefit from encompassing the two important domains of family transitions (Table 1). An independent household or housing autonomy is seen as one of the essential preconditions of parenthood in literature dealing with the transition to adulthood in Serbia (Tomanović and Ignjatović, 2006; Tomanović et al., 2012). The resources that can be available to a young couple in this sense include personal funds (or creditworthiness), parental financial assistance, inherited real estate, or the parental home (which allows autonomy to a lesser or greater extent). The strategies that young parents can apply range from reducing their demands, or rather life within the parental household (sharing the same rooms) to increasing resources or buying or renting real estate with their own funds, buying/enabling (inheritance) by the family of origin, or expanding the family home.

With regard to financial autonomy, there are demands relating to financial independence from parents, sufficient income, and young woman's financial independence. Resources available include those from employment, rents, social transfers, and parental support. Strategies that couples pursue range from reducing costs and meeting only basic needs, to doing extra work, working overtime, own production of goods (e.g. food, clothing) or receiving regular financial and in-kind transfers from parents (Tomanović et al., 2012).

Work-related demands may include insecurity (work without or with fixed-term contract), mandatory overtime work, or nonstandard schedules, while potential resources in this domain are the possibility of flexible arrangements, sensitised work culture towards parenthood, and legal solutions related to parental leave. To reconcile the different domains, young couples may choose to have one of them leave the job, work less or occasionally, or try to increase resources through various forms of additional work (Voydanoff, 2005).

Finally, on the side of family demands, there are childcare, household tasks and partnership demands. Key resources within the family include mutual support between partners and support from kin networks. To reconcile different requirements within the family domain, a couple can trade-off a career versus a parental role with a spouse, decide in advance to spend less time with children and family or increase resources through informal or paid support (Voydanoff, 2005).

Through this approach we bring together different factors: demographic, structural, economic and institutional, which constitute the social context of young parenthood. In addition, the framework that could be labelled cultures of parenthood includes gender regime as its significant aspect: the variety of complex institutional relations between the productive and reproductive spheres, which determine gender practices and gender relations within the social system (Walby, 2004: 10). The normative gender order - normative expectations of gender roles in different 
domains: work, politics, family (du Bois-Reymond, 2008) is significantly related to different opportunities and constraints that young mothers and fathers experience.

This paper focuses on the resources (housing, finance, employment) that are available to young parents, which we understand as the structures of parenthood shaped by broader socio-economic and institutional frameworks, as well as on the strategies couples apply as an expression of their agency within a context marked also by dominant cultures of parenthood. The analysis is grounded in the perspectives of individual young parents, their perceptions and experiences.

\section{MIXED METHODS}

Participants: The analysis brings together different data sources and methods used in the research project "Youth - Actor of Social Change" that focused on the transitions to adulthood and social biographies of young people in Serbia (Tomanović et al., 2012). The research was based on an explanatory sequential mixed method design (Creswell, 2012), comprising two phases conducted in 2011 and 2012. The evidence base for the quantitative analysis presented in the paper is survey data obtained from a sub-sample of 435 parents from a representative national sample of 1,627 young people aged 18 to 35 . Therefore, the term "young parenthood" is used to refer to the early phase of parenthood of young people aged 18-35 throughout the paper. The sample design was a multi-stage stratified sample with the principle of a random selection of young people through the random route technique. The four NUTS2 statistical regions divided by urban and rural areas were the basis strata. The process of selection included five phases: municipalities, local communities, streets, households and persons. The respondents are represented in the sub-sample as follows: by sex: $62 \%$ women and $38 \%$ men, by activity status: $10 \%$ of young parents (mostly mothers) are inactive, $22 \%$ are unemployed, and $68 \%$ are employed young persons. Around $16 \%$ of them have primary education, $63 \%$ secondary, $19 \%$ tertiary and $2 \%$ of them are still in the process of acquiring (tertiary) education, while $55 \%$ of respondents live in urban areas and $45 \%$ in rural areas.

The survey was followed by 24 semi-structured interviews with 12 mothers and 12 fathers aged 30 who were selected from the survey sample through theoretical sampling, so that it included two genders (male/female), three different levels of education, employment status (employed / unemployed) and different residences (big city / small town or village) in the territory of three regions in Serbia (Belgrade, central Serbia and Vojvodina). Respondents aged 30 were selected since previous studies on young people in Serbia have shown that this age represents a symbolic threshold after which adulthood is assumed, as opposed to the age of 25 which 
was a symbolic marker in their parents' generation (Tomanović et al., 2012). The age range of the respondents' children was from 1 to 11 years. While there is a considerable variation in children's ages, our analysis focused on mothers and fathers in their transition to parenthood and the early phase of parenthood. This justifies examining these parents with young children as a single category, regardless of the noted differences in children's ages. All 24 interviews were conducted face to face, recorded and transcribed. The average duration of the interview was 60 minutes. The respondents were informed about the purpose of the research, the content of the instruments, the procedure of selection, and the scientific use of the interviews. All necessary measures were taken to secure privacy and personal data protection, e.g. anonymisation of the quantitative and qualitative datasets.

Instruments: In order to identify the association between the social status of young parents and their resources and strategies, we employed binary logistics and linear regression models. The first two dependent variables are binary: 1. independent household indicates the possession of an independent housing unit, and 2. financial autonomy refers to young people who earn their own income (from work, pension, rent, grant, etc.) and who are not maintained or supported by parents or partners. The other two dependent variables are complex and treated as continuous: housework is a scale composed of the following activities: tidying up, ironing, washing the dishes, washing the clothes, preparing the main course, preparing other meals, grocery shopping, taking out the garbage and paying bills (scale range from 0 to 8); parental care is a scale which includes: feeding, bathing, dressing, putting children to sleep, and playing with children (scale range from 0 to 5). Each activity a household member was involved in during the previous week was counted 1. Young people's SES, employment status and gender were used as independent variables. Having in mind young people's transitional professional position that can cause status inconsistency, we have adopted a stratification rather than class approach and opted for their education level as the most reliable indicator of socioeconomic status (SES). As an indicator of social background, we used the dominant educational position of parents. Age and place of residence (urban vs. rural) are used as control variables. The semi-structured interviews focused on the social biography of the young people - their reconstruction of their transition to adulthood and practices in different life domains.

Procedure: Quantitative and qualitative data were used as complementary: qualitative findings provide interpretation for the quantitative, which contextualise them (Brannen, 2005: 180). The quantitative analysis generates models that explore associations between the main variables (stated above), as well as between the resources and strategies of young parents. Those were further interpreted through qualitative analysis. The semi-structured interview protocol included the 
same themes that were part of the survey: daily life, education and training, employment and work, housing, leisure, social networks, relationship with parents, as well as transition to parenthood, early parenting experience, family and parenting (institutional and informal) support, partnership etc.

Our first assumption, stemming from the first research goal, is that young parenthood in Serbia is formed within a context marked by specific structural and cultural features, which influence resources available to parents and a variety of strategies they deploy to manage these resources. There are two assumptions related to the second research goal, which addresses the relations between resources and strategies. First, we assume that resources are related to macro-social structures and differentiated by the socio-economic status and gender of the young parent. We also assume that young parents' strategies are bounded by structures, resources and the dominant gender order.

The analytical strategy comprised a thematic analysis aiming to explore young parents' practices in different domains (housing, work, informal support) in relation to their SES. The analysis of the respondents' accounts was based on the constant comparative method (Boeije, 2002), and consisted of searching for differences in resources (material status, social ties and networks) and patterns of strategies distinctive to young parent's gender and to their educational level as an indicator of their SES, as explained above. The process of coding was not prescribed, it was based on emergent codes (Creswell, 2012). The coding process involved a constant comparison of statements within specific topics (and their subtopics) transition to parenthood, early parenthood experiences, gender practices, family support, in order to identify typical and distinct patterns. These patterns were linked to the characteristics of the subjects (such as gender, education level) and combined with the quantitative results.

The analytical focus of the paper is on the case study of Serbian society, while general findings are discussed from a comparative perspective in its concluding section. 


\section{THE SOCIAL CONTEXT OF PARENTHOOD IN SERBIA}

\section{The Structural Framework for Young Parenthood}

The literature on a difficult post-socialist transformation in Serbia shows that Serbian society is characterised by a prolonged transition to a market economy, declining production, a delay of the country's political and economic integration into the $\mathrm{EU}$, a growing informal economy, rising unemployment (including precarious employment), and a reduction in social mobility and increasing social inequality (Lazić, 2011; Cvejić, 2006). In such a context, the transition of young people from school to work is limited by considerable structural constraints, such as high dependence on the resources of the parental family (Tomanović et al., 2012), little institutional support for education and employment and an inflexible educational system which does not allow combining education, work and parenting. Besides, there is high unemployment among young people (31.2\% aged $18-35$ in 2014; Labour Force Survey, 2014), the flexibilisation of labour that involves precarious employment, and overexploitation of young people (Tomanović and Stanojević, 2015).

Serbia is characterised by a traditional model of family transition, with a high marriage rate (in $2012,4.8)$, low cohabitation rate $(8.5 \%$ population over the age of 15 , Statistical Office of the Republic of Serbia, 2013), and with a relatively low extramarital birth rate of about $25 \%$. Cohabitation and extramarital births in most cases involve marriage at a later stage. In a period of fifteen years, the average age of first marriage has increased by more than two years (for men 30.6 and for women 27.4 in 2012). Marriage and childbirth are usually synchronised events since most people perceive parenting as the purpose of marriage (Tomanović and Ignjatović, 2006). Young women in Serbia are among the younger women in Europe to give birth to their first child, with an average age of first birth of 27.3 in 2012 (EUROSTAT, 2012). The preferences regarding the number of children are relatively stable and amount to 2.4 on average for young men and women (Tomanović and Stanojević, 2015) but the actual number of children depends on the parents' level of education, whereby women with higher education postpone the transition to parenthood and on average have fewer children (Vasić, Gligorijević and Devedžić, 2014). As women's education increases, the cumulative fertility rate decreases. According to Census 2011 data, in the age cohort 40-49, women with higher education have a cumulative fertility rate of 1.37 and those without any formal education 2.41 (Rašević, 2015).

The labour market is characterised by a gender gap (with $61.9 \%$ of employed men and $49.3 \%$ of employed women) as well as a gender pay gap (8.7 percentage points between men and women in favour of men) (Statistical Office of the Repub- 
lic of Serbia, 2014: 76). The market is not sensitive enough to parental responsibilities and the work culture is still predominantly masculine, without adequate flexible solutions for parents. Paid, full-salary parental leave after childbirth is granted up to one year but only to employed parents. It is mandatory for mothers during the first three months, while the following nine months of leave could be used either by the mother or the father. Since 2001, the Employment Act has granted men the right to take parental leave, but the data indicate that very few of them have used this opportunity (SIPRU, 2016). The practices that would encourage them are not part of practical policies, public discourses, or work cultures. Financial support for families and cash transfers for children are very low and restricted and do not target poor families well (Matković and Mijatović, 2012). Socialism had left a legacy of an affordable public early childhood education and care (ECEC) infrastructure, but this development has been stopped in the last three decades. The coverage is quite low, regionally uneven, significantly less present in rural areas, and amounts to $19.1 \%$ for children up to the age of three and $38.3 \%$ for children aged 3 to 6.5 (Statistical Office of the Republic of Serbia, 2017). This is why most parents mainly rely on informal networks, particularly their parents.

\section{Gender Regime and Cultures of Parenthood}

The division of domestic work and childcare activities are extremely gender asymmetrical (Tomanović, 2010), regardless of the scope of women's employment (Babović, 2009; Blagojević-Hjuson, 2013). The way that the family and private spheres are synchronised involves a high female employment rate and income of both partners, but also a significant degree of persistence of patriarchal values within the private domain. During the period of socialism, Serbia experienced significant effects of gender role modernisation in the public sphere, but the private sphere remained out of policy interest, thus reproducing the patriarchal division of roles, power and domestic labour. In the post-socialist context, this usually leads to a double burden on women, i.e., doing both a full-time paid job and most of the housework (Kovacheva, 2010).

In shaping the cultures of parenthood in Serbia, the familistic pattern is significant: a high value is placed on the family and its formation as a life goal, which makes it central to the transition to adulthood (Tomanović and Ignjatović, 2010). Other characteristics include a hetero-normative frame of married couples with children and a high level of measured support to patriarchal values and attitudes, especially in relation to gender roles in the private sphere (Pešić, 2006). A significant feature of the dominant ideology of familism in Serbia is the ethics of parental sacrifice for the benefit of their children and their best interests, which is supported 
by a majority of parents (Tomanović, 2010). There are two gendered patterns of care: the ethic of maternal care, and the ethic of fathers as providers.

In the next section, we analyse the resources available to young parents and the strategies they employ to respond to the structural and cultural demands of motherhood and fatherhood and related parenting practices. We will try to show how the balance between housing, finances, work and family is established and maintained through the strategies. Based on quantitative data, we will analyse the factors associated with different forms of balance in specific domains. Based on qualitative data, we will then show how respondents interpret their resources and strategies.

\section{YOUNG PARENTS' RESOURCES AND STRATEGIES}

\section{Housing}

The survey data shows that one of the biggest challenges for a young family is the provision of adequate housing. The possession of a first home usually requires the support of parents, as indicated by data showing that a quarter of young parents in Serbia who participated in our research still live with their parents (24.9\%). A slightly greater number live in an inherited home $(27.3 \%)$, one in ten $(10.6 \%)$ young parents live in an apartment / a house bought by their parents, one quarter are renting, while only one in ten $(12.2 \%)$ have bought their home on their own. When starting a family, a significant number of young people rely on their parents' resources, either by forming a new family within the parents' household or by receiving substantial financial contribution when buying property.

Table 2: $\quad$ Logistic regression model - factors associated with independent household

\begin{tabular}{lcc}
\hline Independent household & $\mathrm{B}$ & $\mathrm{Exp}(\mathrm{B})$ \\
\hline Primary school & $-1.230^{*}$ & .292 \\
Secondary school (ref. tertiary) & -.147 & .863 \\
Parents - primary school & $-1.441^{*}$ & .237 \\
Parents - secondary school (ref. tertiary) & $-1.120^{*}$ & .326 \\
Unemployed (ref. employed) & .587 & 1.798 \\
Financial autonomy (ref. no autonomy) & $.662^{*}$ & 1.938 \\
Urban (ref. rural) & $.990^{*}$ & 2.692 \\
Constant & .038 & 1.039 \\
\hline Nagelkerke $\mathrm{R}^{2}$ & \multicolumn{2}{c}{.203} \\
\hline
\end{tabular}

${ }^{*} p<.05 ;{ }^{* *} p<.001$ 
The results of our logistic regression show that the factors associated with housing independence are social background (measured by parental education level), social status (measured by the education level of respondent), financial autonomy and place of residence of young parents (Table 2). Parental education proved to be a more important factor associated with having an independent household than young people's financial resources. In particular, the chances for young parents with university degrees to live independently are three times larger compared to those who have completed only primary school education. If these educated young parents are financially independent, then there are even greater chances that they will form an independent household. Furthermore, an important factor in having an independent household is also the place of residence: young people who live in a village are 2.5 times more likely to live with their family of origin than the youth who live in a city. This can be explained by the availability of housing within the relatives' network in rural areas.

The interviewed young people reveal that their housing strategies are connected with their SES as indicated by their educational levels. The worst housing conditions were described by the parents with a primary-school education. Among them, no one possesses a flat. As many as three out of four respondents live within extended families, whereas only one rents an apartment. All these new families have been established within the household of the family of origin by a room being freed for them. In three families, children do not have a separate room, but live in the same room as their parents. When the children are young, parents do not seem to feel their children need additional living space, but they do recognise this as a problem as they grow older. A father with a primary education describes this as follows: "Well, it is a bit of a problem for us, since the older child is 9 and for this one here, the little one, it isn't such a problem like it is for the older one", or a mother who says: "Since they are little, we can still sleep in one room. Later, when they grow up, if we don't get the chance to have something of our own, we will look for a flat with two rooms."

Young people with a vocational education also often start a family within their parents' household, but they are more likely to have better housing conditions, because life with their parents involves a larger part of the house, or a separate housing unit. For example, a mother with a vocational education mentioned how she and her husband renovated the second floor of his parents' house where they gradually started to live independently.

...there were only walls and windows. We raised a loan and reconstructed the bathroom, then we put some money aside, took it from our salaries and bought a kitchen. My parents bought us a lot. Then we had only two rooms, a kitchen 
and a small room. Then, we bought furniture - piece by piece with the loan, and arranged the living room.

None of the interviewed parents with a secondary education had purchased property independently, but they appear to be in a better position than their less-educated peers since they have better financial abilities to lead independent lives as well as the possibility of relying on their parents to help them financially.

Finally, the young parents who have university degrees are in the best position. If they still live with their parents, they have clear plans to get a loan and buy a property. On the other hand, those who do not live with their parents have either bought an apartment on a loan or are renting.

\section{Finance}

The young parents' sources of income also show that they still receive significant support: every twentieth young parent from the survey is still being financially supported by their parents, young mothers and young fathers (Figure 1) equally. About one-half of young parents have a personal income, while every fourth father has no income from work, which is the case with more than one-half of mothers. Every third woman is supported by her partner and every twentieth man, too. Only $61 \%$ of young parents are completely financially independent (from the parents and/or partner/spouse).

Figure 1: Financial autonomy of young parents

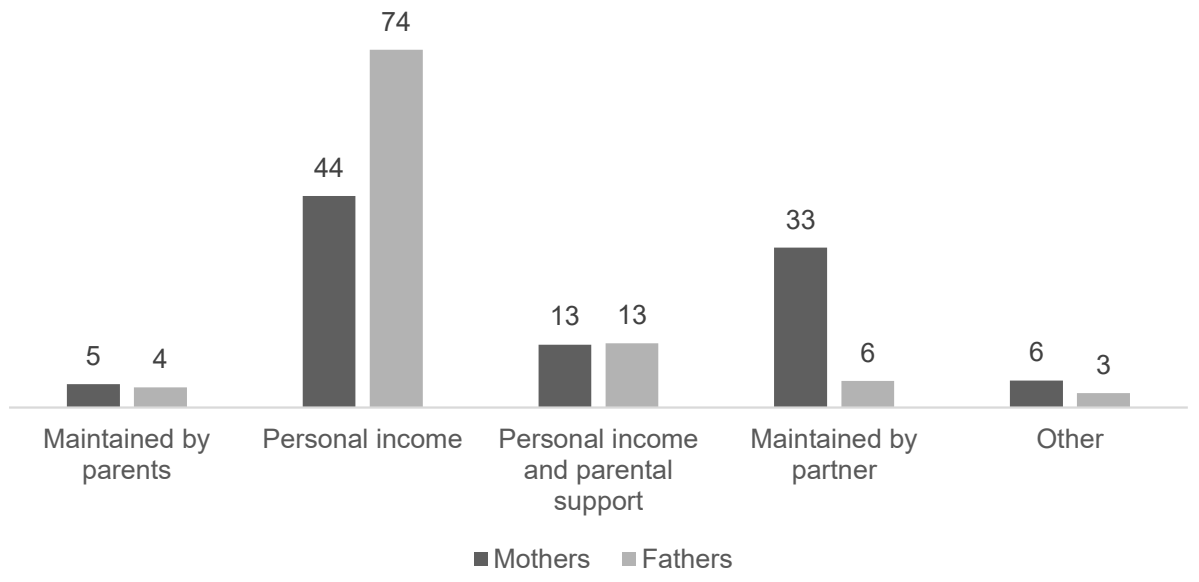


In order to extract the key factors that influence the degree of financial autonomy of young parents we made the following regression model (Table 3).

Table 3: $\quad$ Logistic regression model - factors associated with the financial autonomy of young parents

\begin{tabular}{lcc}
\hline & \multicolumn{2}{c}{ Financial autonomy } \\
\hline Primary school & B & Exp B \\
Secondary school (ref. university) & .707 & 2.029 \\
Unemployed (ref. employed) & -.016 & .984 \\
Urban (ref. rural) & $-2.263^{* *}$ & .104 \\
Sex (ref. female) & .269 & 1.308 \\
Age & $.806^{*}$ & 2.239 \\
(Constant) & $.493^{*}$ & 1.637 \\
\hline Nagelkerke $\mathrm{R}^{2}$ & -2.029 & .132 \\
\hline${ }^{*} \mathrm{p}<.05 ;{ }^{* *} \mathrm{p}<.001$ & \multicolumn{3}{c}{.367} \\
\end{tabular}

The model suggests that financial autonomy is associated with the employment of a young person. Besides, fathers are more likely to be fully financially autonomous compared to mothers, which indicates a higher degree of women's dependence both on parental families and their husbands. The probability that a young parent becomes financially autonomous expectedly increases with their age.

The analysis of the interviews indicates that young parents deploy several strategies in order to ensure the maintenance of their families. The most widespread is the combination of various incomes gained from formal and informal work. Since one father's salary as a butcher fails to provide all the necessities, he complements the household budget with additional agricultural work:

Salary is not enough, but I say again, I have the cattle, well, so I earn a little there, then I slaughter cattle when someone asks for my service. I try to draw some money out of these cattle, as much as I can, so that we can move on.

Doing multiple jobs is sometimes supplemented by another important strategy support from their parents, both financial and non-financial:

Well, we don't choose. We'll do just about anything. My husband chops wood whenever someone asks him to. He has a friend, a musician, whom he packs instruments with. That is also how we earn extra money. So, whenever we hear there's a job to be done, we do it. His mom and dad also give us money and, 
like, food, and my parents, too. That's how we survive. ... So, may children be safe and sound, and everything else will be all right. (mother, vocational school).

Most of the interviewed young parents indicate that the income they generate is not sufficient for the kind of life they would like to live. Those with higher education degrees are more satisfied with their financial situation, but at the same time, their expectations are higher as well.

The perception of what is sufficient for the life of a family varies considerably: from a highly educated professional who works in the NGO sector, who, besides regular and part-time jobs, feels a certain dissatisfaction since she still cannot afford to buy a flat with her husband, to a mother with a vocational education, who must build a long-term strategy in order to buy basic necessities for life.

So once that, I do not know, I do not have to check the price of this, the price of that, and to buy everything I need to buy. For example, my son needed socks, I do not know, and now, this is just one example, and ... my girl needed the socks as well ... And now I have to choose whether to buy socks for one kid this month, and the other one the second month. It has to be done like that.

Respondents point out that it is important to have at least one steady source of income, if possible, from the public sector. An unemployed father with secondary education says that in the case of his family currently it is his wife who earns and provides for the family:

Well, if I may put it like this, my wife and I, we always fit together. At least, she works in the state company and has a permanent salary which she knows she will receive every tenth in the month, so we complement each other.

The young parents with lower SES are more likely to receive material help from their relatives, while fathers are more likely to get a job additional to their formal employment. On the other hand, the parents with a higher education tend to rely on themselves, as a mother who works in a school testifies: "Nobody helps us, neither financially, nor mentally, nor physically or ... (laughs)." These parents usually have enough resources to balance between their private and professional life, and maintain relationships with their parents without a (daily) exchange of resources.

Material help from parents varies from almost complete support to temporary assistance in the form of finance or goods, while there are also young parents with sufficient resources who insist on being fully independent. An unemployed mother with a primary education reports that, although they are in a very unfortunate posi- 
tion with no one to rely on financially, their parents who live in a village help them in other ways:

(S)ometimes my parents, sometimes his parents give our children five hundred or a thousand dinars. That's all. We get potatoes, eggs from the village. I don't buy that. I bring the basic goods from the village like cheese, cream, milk.

\section{Employment as a Resource and Employment Strategies}

The way young parents reconcile parenthood and work depends on their position in the labour market, which is influenced by their education and gender.

Figure 2: Employment status of young parents

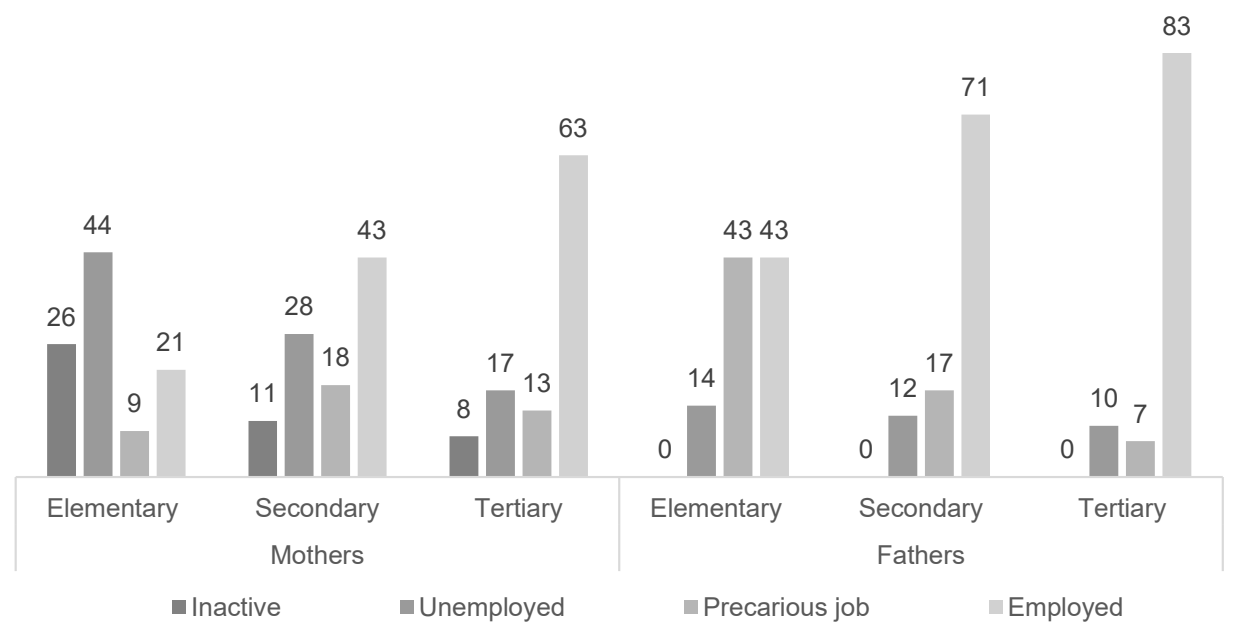

Figure 2 shows that fathers are more present in the labour market, compared to mothers who are more often inactive and unemployed. Becoming a father implies increasing involvement in the labour market for many men. On the other hand, for some women it implies temporary or permanent withdrawal. With the increase in parents' education level, the uncertainty of their position in the labour market decreases. Mothers with low levels of education are more likely to become inactive and unemployed.

The analysis of young parents' interviews has yielded two types of employment strategies. In the first one, the father is employed and his income is crucial, while the mother usually does not work or if she does, her salary is an extra. In the sec- 
ond, both parents work and their earnings are more or less equally important to support the family. The first type seems to be a work-family strategy among young parents with vocational and primary education, while the other is evidenced among the highly educated / professionals.

In the first case, the exclusion of women from the labour market is a result of a traditional pattern of the work-family balance, which is under the strong influence of the patriarchal gender regime, and usually does not include negotiations or agreements, or a rational decision of spouses. One mother with a primary-school education that has never worked stated that her husband had strongly opposed her wish to work. Another mother, also with a primary education, explains that even though she was forced to find a job recently due to financial necessity, she had not been employed since she got married, and after her children were born, she did not search for a job.

On the other hand, the working environment is unregulated and still insensitive to parental responsibilities, thus preventing women from obtaining a steady job. After becoming pregnant, some women are fired or leave work as evidenced in the interview with a mother with a vocational education who pointed out that she had been employed until 2009 "and then I got pregnant, and quit. In 2010 I started again. I mean, I have to. ... I go from house to house, cleaning." Similarly, a young craft worker describes the history of his wife who had worked "until her first pregnancy. Then she returned to her job, but became pregnant again. So, she left her job. There were some terms that she could not accept - working at night, with much lower wages than the first time."

In the second pattern, both men and women work and generate income and mostly live solely on their salaries from formal employment, whether they work in the public or private sector. Work positions of professionals (with university degrees) are more often permanent, especially if they work in the public sector. These jobs offer greater satisfaction and a significant source of identity. The highly educated professional mother lists the advantages of her job in a school:

For a woman who has a family, a school is a perfect place, Saturdays and Sundays are free ... Well, during the winter break we go to work but that's the documentation, the paperwork, so you do your job while drinking coffee ... Summer is the same - a month and a half of real break, we do not go to school during July and half of August. 


\section{Work Family Balance Strategies}

Congruent with their greater involvement in the labour market, fathers are less involved in housework (Figure 3) and childcare activities (Figure 4), which is also related to high support for the traditional division of domestic labour.

Figure 3: Participation of mothers and fathers in housework

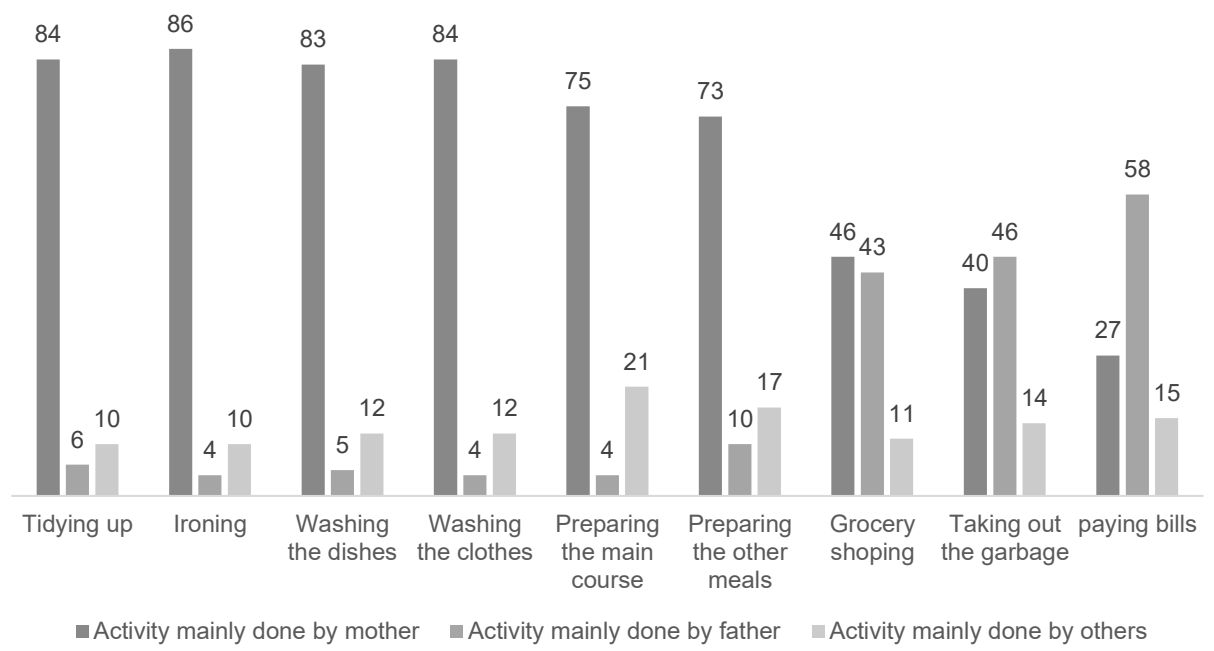

Figure 4: Participation of mothers and fathers in childcare

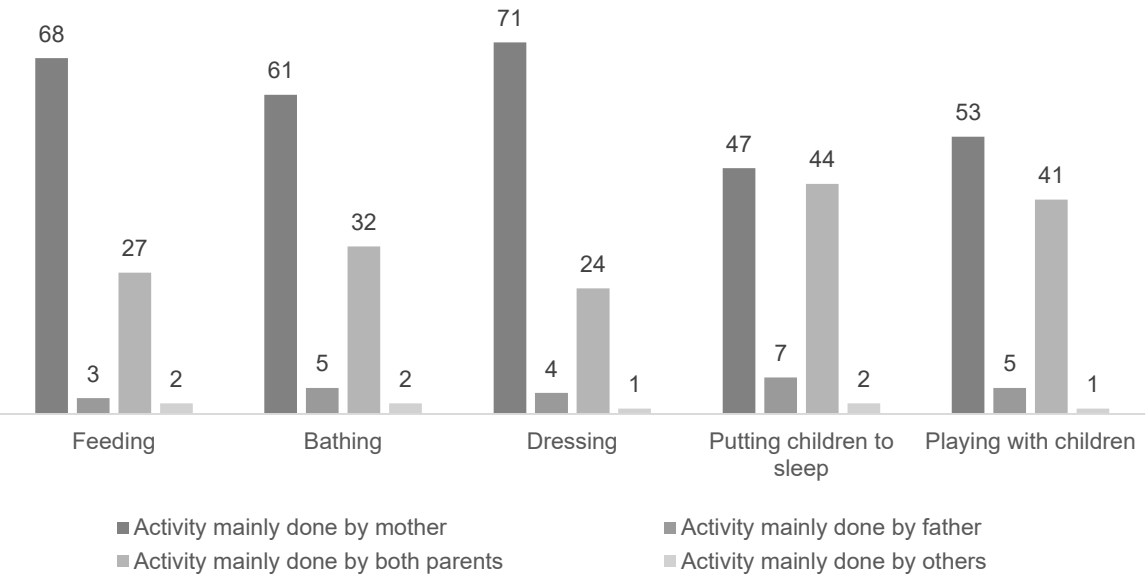


In order to test resource significance for the level of involvement in household chores, we created two regression models (Table 4).

Table 4: $\quad$ Regression models - factors associated with parents' involvement in housework and parental care

\begin{tabular}{|c|c|c|c|c|c|c|c|c|}
\hline & \multicolumn{2}{|c|}{$\begin{array}{l}\text { Fathers - } \\
\text { housework }\end{array}$} & \multicolumn{2}{|c|}{$\begin{array}{l}\text { Mothers - } \\
\text { housework }\end{array}$} & \multicolumn{2}{|c|}{$\begin{array}{c}\text { Fathers - } \\
\text { parental care }\end{array}$} & \multicolumn{2}{|c|}{$\begin{array}{l}\text { Mothers - } \\
\text { parental care }\end{array}$} \\
\hline & B & Beta & B & Beta & B & Beta & $B$ & Beta \\
\hline (Constant) & $3.148^{* *}$ & & $5.772^{* *}$ & & $2.461^{* *}$ & & $4.598^{*}$ & \\
\hline Primary school & -0.924 & -0.207 & $.873^{*}$ & 0.176 & $-1.762^{\star *}$ & -0.351 & -0.199 & -0.097 \\
\hline $\begin{array}{l}\text { Vocational school } \\
\text { (ref. university) }\end{array}$ & -0.386 & -0.124 & 0.524 & 0.134 & $-.832^{*}$ & -0.22 & -0.007 & -0.005 \\
\hline $\begin{array}{l}\text { unemployed } \\
\text { (ref. employed) }\end{array}$ & 0.431 & 0.088 & $.924^{* *}$ & 0.237 & $-.542^{*}$ & -0.135 & 0.152 & 0.092 \\
\hline $\begin{array}{l}\text { Spouse } \\
\text { unemployed (ref. } \\
\text { spouse employed) }\end{array}$ & $-.612^{*}$ & -0.208 & 0.00 & 0.00 & -0.118 & -0.028 & -0.075 & -0.044 \\
\hline $\begin{array}{l}\text { Extended } \\
\text { household } \\
\text { (ref. nuclear family } \\
\text { household) }\end{array}$ & -0.428 & -0.138 & $-1.722^{\star *}$ & -0.414 & -0.194 & -0.049 & 0.034 & 0.021 \\
\hline Urban (ref. rural) & -0.105 & -0.036 & 0.295 & 0.076 & 0.231 & 0.063 & 0.08 & 0.053 \\
\hline
\end{tabular}

The analyses of the survey data indicate that the degree of fathers' involvement in housework is associated only with whether their wives work or not. If a wife is employed, the father will be somewhat more involved in housework. On the other hand, the mothers' degree of engagement in household chores depends on their education, employment status, and whether they live within an extended household. Education, employment and informal support networks are very important resources which primarily enable a woman to share domestic duties with others. On the other hand, when it comes to parental obligations, analyses show that, with increasing levels of education, fathers engage more often, but if they are unemployed, they become less involved. The last finding suggests that, in predominantly patriarchal societies, a lack of resources for men is compensated with power in the private domain - the power not to engage in childcare. Fathers' engagement does not depend on whether their wives work or not. The findings that the degree of mothers' involvement in childcare does not vary at all in relation to their resources indicate that mothering is the primary parental role. 
These data are in accordance with interview insights concerning the division of housework. The majority of household chores fall on young mothers: "the house, the kids, lunch" are their responsibilities. A mother with primary education states that she does "almost everything", while an employed mother with secondary education says:" "I have to do everything, I have to take our child to kindergarten, to return it home, to cook, to clean up, to wash up. Absolutely everything."

Most fathers also describe that household chores are divided along gender lines. The differences appear in the way this division of work is interpreted. Men with primary and secondary education find this division to be self-explanatory and do not question it. As a father with a vocational education says: "I work outside, she works inside, which means she does not work outside and neither do I inside." Another father who works in agriculture and lives in a village explicitly states that a different division of work in the household would be a source of frustration for him: "You know when I would not be satisfied? When I would have to vacuum, to iron, to cook ... Basically, I am, as they say, 24 hours - 25 hours on my feet ... I can help sometimes, but we all know what male and what female jobs are." In the interviews with fathers with a university education, we notice that they are inclined towards a more symmetrical division of housework, yet more on a normative level - in terms of attitudes, but somewhat less in practice, as the next example shows: "She does the ironing, I walk the dog and do grocery shopping, as for taking care of the child, we equally participate when it comes to changing clothes and stuff".

A very common strategy of young parents is to rely on their parents' support for childcare and household chores. Their expectation is based on the script - the norm of parenting as a sacrifice. This reasoning is not subject to negotiation: it is a pre-established rule by which they as children are entitled to receive help and support from their parents. The way in which help is expected occurs in two ways: unconditional help or as one female respondent says: "for everything I need" or help on call - when they need it. The expectation of unconditional support means that their parents provide material, instrumental and emotional support. Thus, an unemployed mother with a vocational education says that she expects from her parents "all sorts of help ... just when I need something ... for everything." They expect instrumental assistance from mothers (childcare, housework, etc.) and emotional support too. The account of an unemployed mother with a vocational education describes a type of unconditional intergenerational solidarity that is more common among female than male respondents:

... I get much more help from my mother than my father ... with everything. She simply takes care of me. When I'm sick, she literally runs to help me, if I need something for the kids, and no matter what. And the children, when they are 
sick, she helps me quite a lot. Sometimes she comes here and tells me: 'Get some rest, l'll be with them'.

Help on call represents a pattern of support in which young parents seek help from their parents only when necessary, usually when grandchildren need to be taken care of. In this case, young parents rely almost exclusively on the female family line: on their mother and /or their partner's mother. It is typical for young fathers to seek help from their parents when they go out with their wives: a father with a vocational education can also count on his parents to babysit in order to give him and his wife "some time to relax". Mothers ask for help not for going out but to do some of the work outside or inside the home: "when you really cannot do anything else, when we cannot make it on our own" (a mother with a university education).

\section{DISCUSSION}

The special features of young parenthood in Serbia are formed within a context marked by multiple risks for young parents that are related to the country's social transformation. Our research has provided evidence that the macro-social context puts considerable structural constraints on young parents, where high unemployment, relatively low income and the lack of regulation of employment conditions are the most important causes of financial vulnerability and insecurity.

The family transition of young couples can be demanding in several key areas. The answers to these demands depend on the resources that couples possess as well as the family and gender norms that shape their family practices. Facing structural constraints, young parents most frequently use two kinds of strategies which are gender-distinctive and diversified by their SES. The first is an increase in resources (as in Voydanoff, 2005). Housing resources at the disposal of young parents are modest and mostly generated from the family of origin. There are unequal opportunities for housing independence among the young parents, with better chances for those with more affluent parents, higher education, a better position on the labour market, and higher incomes. An independent household provides a more egalitarian gender distribution of household tasks and more chances for a better harmonisation of work and home responsibilities of women.

Almost all young fathers strive to increase their family's resources in the labour market, through overtime work, additional jobs, and less job selection. There are, nevertheless, important SES differences: the chances to obtain a job, a permanent contract, higher income rise with an increase of the educational level of young fathers, which are also related to ampler resources of their parents. Although all 
men are expected to increase their activity in the labour market, those with a lower education are more likely to have to work illegally, overtime, on additional and precarious jobs than those with a higher education who are more likely to have their labour rights protected.

When it comes to organising family life, for most young parents, there are high expectations of support from their parents, which indicates a specific cultural pattern of intergenerational solidarity. The analysis indicates a social and gender differentiation of this strategy. On the one hand, the nature and extent of expected help and support is associated with the level of the young parents' personal resources. On the other hand, the interview analysis has revealed that young mothers are more prone to expect and receive help in childcare and also emotional support from their female relatives, particularly at the early mothering phase - with their baby.

Another set of strategies is related to the reduction in demands. It occurs far more frequently among young parents with lower resources: living within an extended family, leaving education, quitting a job, and lowering of career ambitions are more common among young parents with a lower education. There is a reduction or at least adjustment of demands for optimal housing, so starting a family usually happens in the parental household. Living together with their parents, cramped living conditions and lowering of financial demands are, nevertheless, rarely present among young parents with a higher education whose parents have considerable resources. Living in an extended family household is a significant context for parenting in Serbia and its priority is the provision of financial security and facilitating the work-family balance for young parents.

There is also a gendered reduction strategy of the work-family balance that is more common among lower-educated women, who often give up both their education and, temporarily or permanently, their employment. Faced with risks in the labour market, insecure work engagements, undeclared work, inflexible hourly rate, and given that part-time work and flexible arrangements are not common options, a number of lower-educated women most often choose to leave work temporarily or permanently. Together with living in the extended family household, this kind of withdrawal reproduces the asymmetry in gender and generational relations, strongly binding young mothers to the private sphere and caring practices and networks, thus excluding them from the public sphere and sociability. Unlike those with a higher education, where both men and women reconcile family and professional obligations both individually and together as a couple, those with a lower education reconcile these more often along traditional lines, so that women take over entirely the private and men the economic sphere, where the parental role versus job and income trade-off among spouses is obvious. 
The transition to parenthood in Serbia bears certain similarities and particularities in comparison to dominant models in Europe. Becoming a parent is a central part of the transition to adulthood, both on a normative-symbolic and practical level: it is perceived as a marker of adulthood, and also as part of a mechanism of becoming independent from the family of origin (Tomanović and Ignjatović, 2006; 2010). In this way, this pattern is similar to the Southern European model of transition to adulthood with the extended dependence on parental family (Biggart and Kovacheva, 2006; du Bois-Reymond, 2008), where independence from parents is realised through the formation of one's own family (lacovou, 2002). This model of transition to adulthood is based on the sub-protective welfare regime and transition regime with its post-socialist type (Walther, Stauber and Pohl, 2009). Therefore, some features of young parenthood in Serbia resemble those in Southern and Eastern European countries. Informal support for parenting in familial societies that relies on intergenerational solidarity is evidenced in Bulgaria, Slovenia and Italy (du Bois-Reymond, 2008: 91), particularly grandparents providing help to young parents with childcare, as in Slovenia, Portugal and Bulgaria (Nilsen et al., 2013a: 97). Serbia resembles most of the post-socialist countries with its institutional frameworks of support to parenthood (Thévenon, 2011), which include long, paid parental leave that is gendered, and mostly targeted to mothers ${ }^{3}$ (Brannen, Lewis and Nilsen, 2009: 180; Dobrotić and Stopnik, 2020). As in other post-socialist countries, in Serbia, such long leaves are a result of the rationale that "the mother's moral duty to take care of their young children rather than return to the workplace ... with the ideal of mother-centred care rather than gender equality" (Dobrotić and Stopnik, 2020: 509). Serbia is characterised by an under coverage of ECEC institutions, and with very low cash transfers and benefits for childcare unlike in Slovenia (du Bois-Reymond, 2008: 31).

With regard to the features of the gender regime, which heavily relies on traditional gender roles in relation to family life, Serbia resembles some Balkan countries such as Bulgaria (Kovacheva, 2010). Together with low income, high unemployment and low flexibility of work for parents (du Bois-Reymond, 2008: 34), in the working environment that is not "family-friendly", those features create an extremely challenging context for working parents (particularly mothers) in countries such as Bulgaria (Brannen, Lewis and Nilsen, 2009: 186) and Serbia. Nevertheless, the particularities of the context of a country that is still in the process of EU accession - a highly unregulated and gender-biased labour market, with weak and corrupted institutional support and high risk of poverty - produce additional risks for young parents in Serbia.

Slovenia is among the most gender-equal postsocialist countries when it comes to policies, leave and ECEC coverage (Dobrotić and Stopnik, 2020). 


\section{CONCLUSIONS}

Complementary use of analytical frameworks derived from transition to parenthood and Work-Family balance perspectives proved fruitful in linking different levels of sociological exploration of young parenthood. The study findings have confirmed that demands of young parenthood, resources available to parents and the strategies they deploy are determined by structural and cultural constraints and opportunities originating from a specific social context in Serbia today. The mixed-method analyses contribute to the exploration of the complex interplay of resources and strategies that are diversified by young parent's SES and gender. There is evidence that unequal available resources (housing, finance, work, informal support) that are under the influence of macro-social structures, are strongly related to the SES of a young parent, and so are the strategies (of decreasing demands and increasing resources) they develop and use. We can, therefore, argue that the transition to parenthood and young parenthood could be seen as other fields of social reproduction of socio-economic inequalities. Fostered by structural constraints and institutional deficits (as limited resources), the gender- diversified strategies young parents deploy, which pull young women with a lower SES out of the labour market and into the private domain of mothering supported by a strong female informal network, further reinforce the dominant gender regime in the cultures of parenthood in Serbia. On the other hand, these gendered strategies are also resource-dependent and related to SES: our findings indicate that young parents with substantial personal resources (education, income, housing) strive for more egalitarian practices in parenthood.

The paper also contributes to the comparative studies of transition to adulthood and parenthood by arguing for the need for contextualisation within the dominant models as they are considered in the relevant literature. Although there are several similarities with the countries belonging to the SEE model, the evidence of particularities of the multidimensional context of what we call the structures and cultures of parenthood, which influence the transition to parenthood and young parenthood in Serbia, provides support for the argument that the issues should be explored as a country case study in comparison to the relevant models, rather than as belonging to one of them.

\section{FUNDING}

The research was part of the project supported by the Ministry of Education and Science of the Republic of Serbia (under grant number 179035), and by the Re- 
gional Research Promotion Programme in the Western Balkans (RRPP), which is run by the University of Fribourg upon a mandate of the Swiss Agency for Development and Cooperation, SDC, Federal Department of Foreign Affairs. The views expressed in the paper are those of the authors and do not necessarily represent opinions of the SDC and the University of Fribourg.

\section{REFERENCES}

Babović M (2009). Radne strategije i odnosi u domaćinstvu: Srbija 2003-2007 [Work strategies and relations in households in Serbia 2003 - 2007]. In: Milić A, Tomanović $\mathrm{S}$ (eds.). Porodice u Srbiji danas u komparativnoj perspektivi [Families in Serbia Today in Comparative Perspective]. Belgrade: Institute for Sociological Research at Faculty of Philosophy, 135-151.

Bagić D, Dobrotić I, Lažnjak J, Rodik P and Vučković Juroš T (2017). Coping Strategies of Economically (Partially) Inactive Households: The Case of Croatia, Südosteuropa 65(3): 542-564. https://doi.org/10.1515/soeu-2017-0034

Biggart A and Kovacheva S (2006). Social Change, Family Support and Young Adults in Europe. In: du Bois-Reymond $\mathrm{M}$ and Chisholm L (eds.). The Modernisation of Youth Transitions in Europe. San Francisco: Jossey Bass, 49-61. https://doi.org/10.1002/ cd.168

Blagojević-Hjuson M (2013). Rodni barometar u Srbiji: Razvoj i svakodnevni život. [Gender Barometer in Serbia Development and Everyday Life]. Beograd: UN Women.

Boeije H (2002). A Purposeful Approach to the Constant Comparative Method in the Analysis of Qualitative Interviews, Quality \& Quantity, 36: 391-409. https://doi. org/10.1023/A:1020909529486

Brannen J (2005). Mixing Methods: The Entry of Qualitative and Quantitative Approaches into the Research Process, International Journal of Social Research Methodology, 8 (3): 173-184. https://doi.org/10.1080/13645570500154642

Brannen J, Lewis S and Nilsen A (2009). In Conclusion, In: Lewis S, Brannen J and Nilsen A (eds.). Work, Families, and Organisations in Transition, European Perspective. Bristol: The Policy Press, 179-188.

Creswell JW (2012). Educational Research: Planning, Conducting, and Evaluating Quantitative and Qualitative Research (4th ed.). Boston, MA: Pearson Education, Inc.

Cvejić S (2006). Korak u mestu - društvena pokretljivost u Srbiji u procesu postsocijalističke transformacije [An Idle Step. Social Mobility in Serbia during Post-socialist Transformation]. Belgrade: Institute for Sociological Research at Faculty of Philosophy.

Dobrotić I and Stropnik N (2020). Gender Equality and Parenting-Related Leaves in 21 Former Socialist Countries, International Journal of Sociology and Social Policy, 40 (5/6): 495-514. https://doi.org/10.1108/IJSSP-04-2019-0065

du Bois-Reymond M (ed.) (2008). Young Parenthood, Agency and Social Change. Thematic report, Deliverable No. 19 of the project Youth - Actor of Social Change (UP2YOUTH). https://www.up2youth.org/downloads/task\%2cdoc_download/gid\%2c71/index.html (10 October 2017). 
EUROSTAT database, Mean age of women at childbirth and at birth of first child https:// ec.europa.eu/eurostat/databrowser/view/tps00199/default/table?lang=en (10 November 2017).

Frone MR (2003). Work-family balance. In: Quick JC and Tetrick LE (eds.). Handbook of Occupational Health Psychology. Washington DC: American Psychological Association, 143-162. https://doi.org/10.1037/10474-007

Grzywacz JG and Carlson DS (2007). Conceptualizing Work-Family Balance: Implications for Practice and Research, Advances in Developing Human Resources, 9(4): 455-471. https://doi.org/10.1177/1523422307305487

lacovou M (2002). Regional Differences in the Transition to Adulthood, The Annals of the American Academy of Political and Social Science, 580 (1): 40-69. https://doi. org/10.1177/000271620258000103

Kovacheva S (2010). Work-Life Balance: Young Working Parents Between Opportunities and Constraints. Sofia: East-West.

Labour Force Survey (2014). Statistical Office of the Republic of Serbia.

Lazić M (2011). Čekajući kapitalizam [Waiting for Capitalism]. Beograd: Službeni glasnik.

Lewis S, Brannen J and Nilsen A (eds.) (2009). Work, Families and Organizations in Transition. European perspectives. Bristol: Policy Press. https://doi.org/10.2307/j. ctt9qgprc

Matković G and Mijatović B (2012). Program dečijih dodataka u Srbiji [The Program of Child Allowances in Serbia]. Belgrade: UNICEF and CLD.

Mills $M$ and Blossfeld $\mathrm{H}$ (2003). Globalization, uncertainty and changes in early life courses, Zeitschrift für Erziehungswissenschaft 6: 188-218. https://doi.org/10.1007/s11618-0030023-4

Nilsen A, Brannen J and Lewis S (2013a). Introduction. In: Nilsen A, Brannen J and Lewis $S$ (eds.). Transitions to Parenthood in Europe. A comparative life course perspective. Bristol: Policy Press, 1 - 8. https://doi.org/10.2307/j.ctt9qgtft.6

Nilsen A, das Dores Guerreiro M, Kovacheva S and Smithson J (2013b). Comparing transitions to motherhood across contexts. In: Nilsen A, Brannen $\mathrm{J}$ and Lewis $\mathrm{S}$ (eds.). Transitions to Parenthood in Europe. A comparative life course perspective. Bristol: Policy Press, 41 - 66. https://doi.org/10.2307/j.ctt9qgtft.9

Pešić J (2006). Persistence of traditionalist value orientations in Serbia, Sociologija, 48 (4): 289 - 307. https://doi.org/10.2298/SOC0604289P

Rašević $M$ (2015). Fertilitet ženskog stanovništva. [Fertility of the female population]. In: Nikitović V (ed.). Populacija Srbije početkom 21. veka. [Population of Serbia at the beginning of the 21st century]. Beograd: Republički zavod za statistiku, 74-95.

Statistical Office of Republic of Serbia (2013), 2011 Census of Population, Households and Dwellings in the Republic of Serbia, Families. Beograd: Republički zavod za statistiku. https://publikacije.stat.gov.rs/G2013/Pdf/G20134017.pdf (10 October 2017).

Statistical Office of the Republic of Serbia (2014). Women and Men in Serbia. https:// publikacije.stat.gov.rs/G2014/Pdf/G20146008.pdf (10 October 2017).

Statistical Office of the Republic of Serbia (2017) Preschool education database. http:// devinfo.stat.gov.rs/Opstine/libraries/aspx/dataview.aspx (10 November 2017).

The Social Inclusion and Poverty Reduction Unit (SIPRU) and World Bank (2016). Mogućnost pristupa ekonomskim šansama u Srbiji za žene [The ability to access economic opportunities for women in Serbia]. Belgrade: SIPRU. 
Thévenon O (2011). Family Policies in OECD Countries: A Comparative Analysis, Population and Development Review 37 (1): 57-87. https://doi.org/10.1111/j.17284457.2011.00390.x

Tomanović S i Ignjatović S (2006) Attitudes on Transition to Adulthood among Young People in Serbia, Sociologija, 48 (1): 55 - 72. https://doi.org/10.2298/SOC0601055T

Tomanović S (2010). Odlike roditeljstva [Features of Parenthood]. In: Milić A, Tomanović S, Ljubičić M, Sekulić N, Bobić M, Miletić-Stepanović V and Stanojević D (eds.) Vreme porodica. Sociološka studija o porodičnoj transformaciji u savremenoj Srbiji [Family Times. Sociological Study on Family Transformation in Contemporary Serbia]. Belgrade: Institute for Sociological Research at Faculty of Philosophy, 177-195.

Tomanović S and Ignjatović S (2010). The Significance and Meaning of Family Transitions for Young People. The Case of Serbia in Comparative Perspective, Annales-Annals for Istrian and Mediterranean Studies. Series historia et sociologia, 20 (1): 27- 40.

Tomanović S and Stanojević D (2015). Young People in Serbia 2015. Situation, perceptions, beliefs and aspirations. Belgrade: FES and SeCons.

Tomanović S, Stanojević D, Jarić I, Mojić D, Dragišić Labaš S and Ljubičić M (2012). Mladi - naša sadašnjost. Istraživanje socijalnih biografijamladih u Srbiji [Young People are Present. Study of Social Biographies of Young People in Serbia]. Belgrade: Institute for Sociological Research at Faculty of Philosophy.

Tomanović S, Stanojević D and Ljubičić M (2016). Postajanje roditeljem u Srbiji: sociološko istraživanje tranzicije u roditeljstvo [Becoming a Parent in Serbia. Sociological Study on Transition to Parenthood], Belgrade: University of Belgrade, Faculty of Philosophy.

Vasić P, Gligorijević V and Devedžić M (2014). Responding to Population Policy - Which Women Can Provide the Greatest Demographic Benefit in Serbia?, Zbornik Matice Srpske za društvene nauke, 148: 541-550. https://doi.org/10.2298/ZMSDN1448541V

Voydanoff $P$ (2005). Towards a Conceptualisation of Perceived Work-Family Fit and Balance: A Demands and Resources Approach, Journal of Marriage and Family, 67 (4): 822-836. https://doi.org/10.1111/j.1741-3737.2005.00178.x

Walby $S$ (2004). The European Union and Gender Equality: emerging varieties of gender regime, Social Politics, 11 (1): 4-29. https://doi.org/10.1093/sp/jxh024

Wallace C (2002). Household Strategies. Their Conceptual Relevance and Analytical Scope in Social Research, Sociology, 36 (2): 275-292. https://doi. org/10.1177/0038038502036002003

Walther A, Stauber B and Pohl A (2009). Youth: Actor of Social Change. Final Report. Tubingen: IRIS. 


\title{
Resursi i strategije mladih roditelja u Srbiji
}

\author{
Dragan STANOJEVIĆ
}

Odeljenje za sociologiju, Filozofski fakultet, Univerzitet u Beogradu, Srbija draganstanojevich@gmail.com

\section{Smiljka TOMANOVIĆ}

Odeljenje za sociologiju, Filozofski fakultet, Univerzitet u Beogradu, Srbija smiljka.tomanovic@gmail.com

\section{Milana LJUBIČIĆ}

Odeljenje za sociologiju, Filozofski fakultet, Univerzitet u Beogradu, Srbija milanaljubicic@yahoo.com

\section{SAŽETAK}

Predmet ovog članka su resursi i strategije koje mladi roditelji koriste kao odgovore na zahtjeve koji dolaze iz različitih domena (stanovanja, financija, rada i obitelji). Strukturne i kulturne karakteristike društvenog konteksta Srbije čine okvir unutar kojega je smješten predmet istraživanja. Zatim su analizirane razlike među mladim roditeljima koje se tiču resursa poput stanovanja, zaposlenja kao i njihove strategije, imajući u vidu njihov socioekonomski status (SES) i rod. Analiza je temeljena na kombiniranim metodama koje uključuju rezultate anketnog istraživanja mladih u dobi od 18 do 35 godina, kao i kvalitativnu analizu polustrukturiranih intervjua provedenih s 24 mladih očeva i majki. Analize upućuju na značajne SES i rodne razlike mladih roditelja u pogledu resursa kojima raspolažu i strategija kojima se koriste, a koje su oblikovane društvenim strukturama i kulturom roditeljstva specifičnom za suvremeno društvo Srbije.

Ključne riječi: mladi roditelji, resursi, strategije, kombinirane metode, Srbija. 